\title{
Erratum to: Transurethral ultrasonography-guided injection of adult autologous stem cells versus transurethral endoscopic injection of collagen in treatment of urinary incontinence
}

H. Strasser - R. Marksteiner - E. Margreiter •

M. Mitterberger - G. M. Pinggera $\cdot$ F. Frauscher •

M. Fussenegger $\cdot$ K. Kofler · G. Bartsch

Published online: 25 May 2010

(C) Springer-Verlag 2010

Erratum to: World J Urol (2007) 25:385-392

DOI 10.1007/s00345-007-0190-7

This article has been retracted by the editorial board.

The online version of the original article can be found under doi:10.1007/s00345-007-0190-7.

H. Strasser ( $₫) \cdot$ M. Mitterberger · G. M. Pinggera

K. Kofler · G. Bartsch

Department of Urology,

Medical University of Innsbruck,

Anichstrasse 35, 6020 Innsbruck, Austria

e-mail: hannes.strasser@uibk.ac.at

R. Marksteiner - E. Margreiter

Institute of Biochemical Pharmacology,

Medical University of Innsbruck, Innsbruck, Austria

F. Frauscher

Department of Radiology II,

Medical University of Innsbruck, Innsbruck, Austria

M. Fussenegger

Department of Otolaryngology,

Sisters of Charity Hospital, Wels, Austria 